\title{
Percutaneous Removal of a Broken and Embolized Transvenous Chemotherapy Port Catheter in the Left Pulmonary Artery by Using a Snare-loop Catheter
}

\author{
Kırılmış Transvenöz Kemoterapi Portunun Sol Pulmoner Arterden Snare Katater \\ Kullanılarak Perkütan Olarak Çıkarılması
}

\author{
Muhsin Kalyoncuoğlu, Semi Öztürk, Gündüz Durmuş, Mustafa Sarı, Mehmet Mustafa Can \\ Haseki Training and Research Hospital, Clinic of Cardiology, Istanbul, Turkey
}

\section{Abstract}

Totally subcutaneous intravascular portacath provide safe and reliable vascular access and is widely utilized for venous access for long-term parenteral administration of medications. Catheter fracture and/or embolization of the catheter fragment in to the heart and or pulmonary artery is a rare and potentially serious complication. When it occurs, a prompt surgical or percutaneous extraction of the embolized foreign body is necessary. We present an asymptomatic case of metastatic colon adenocarcinoma in a patient who had fragmentation of catheter from the connection of the port and migration to left pulmonary arteries. We successfully removed the 10-cm long and 6-Fr diameter fractured catheter segment from the left pulmonary artery via the right femoral vein using a snare catheter with triple loop without complication. Post-procedure course was uneventful and the nature of the vascular access made early ambulation possible. Compared to surgery, percutaneous approach is a less invasive, safe, reliable and effective technique. Therefore, we suggest that percutaneous transcatheter technique for retrieval of embolized or broken catheter fragments should be considered as the first-choice treatment.

Keywords: Endovascular, portcath, left pulmonary artery, snare catheter
Öz

Total subkutan intravasküler portacath, uzun süreli parenteral ilaç uygulaması için yaygın olarak kullanılan güvenli venöz giriş yoludur. Port kateterinin kırıması ve/veya kateter parçasının kalp boşluklarına ve/veya pulmoner sisteme embolizasyonu nadir fakat potansiyel olarak ciddi bir komplikasyondur. Böyle bir durumla karşılaşıması durumunda, embolize yabancı cismin bir an önce cerrahi ya da perkütan çıkarılması gerekir. Biz bu yazıda, metastatik adenokarsinom nedeniyle subkutan venöz port yoluyla ilaç kullanan, ilaç uygulanımı sırasında portun bağlantı noktasından koparak, kırılmış ve sol pulmoner artere embolize olmuş olan yaklaşık $10 \mathrm{~cm}$ uzunluğunda ve $6 \mathrm{Fr}$ çapında katater parçasının sağ femoral ven yoluyla 3 looplu mikro snare katater kullanılarak perkütan yolla çıkarıldığı bir olguyu sunmaktayız. İşlem sonrası dönemde herhangi bir komplikasyon olmadı ve hasta erken dönemde mobilize edildi. Cerrahi ile karşılaştırılığında perkütan yol ile kırılmış ve/veya kalp boşluklarına ve/veya pulmoner sisteme embolize olmuş katater parçalarının perkütan yolla çıkarılmasının daha az invaziv, güvenli ve etkili tedavi seçeneği olduğunu düşünmekteyiz.

Anahtar Sözcükler: Endovasküler, portcath, sol pulmoner arter, snare katater

malignancy (1-4). Catheter fracture and or embolization of the catheter fragment in to the heart and or pulmonary artery is a rare and potentially serious complication. When it occurs, prompt extraction of the embolized foreign body is necessary $(1,3,5,6)$. While surgery was
Address for Correspondence/Yazışma Adresi: Muhsin Kalyoncuoğlu Haseki Training and Research Hospital, Clinic of Cardiology, istanbul, Turkey Phone: +90 5337144547 E-mail: mkalyoncuoglu80@gmail.com

Received/Geliş Tarihi: 10 June 2016 Accepted/Kabul Tarihi: 10 July 2016
${ }^{\circ}$ Copyright 2017 by The Medical Bulletin of Haseki Training and Research Hospital The Medical Bulletin of Haseki published by Galenos Yayınevi. ๑Telif Hakkı 2017 Haseki Eğitim ve Araştırma Hastanesi Haseki Tıp Bülteni, Galenos Yayınevi tarafından basıımıştır. 
performed in the past, currently, endovascular retrieval of embolized catheter fragment is mostly preferred and can be performed easily, safely, and successfully $(3,7-11)$.

We present an asymptomatic patient who had fragmentation of catheter from the connection of the port and migration to left pulmonary arteries. Endovascular removal of the catheter fragment from the left pulmonary artery via the right femoral vein using a snare catheter with triple loop was successfully performed without any complication.

\section{Case}

A 34-year-old male with metastatic colon adenocarcinoma diagnosed in July 2015 was receiving monthly chemotherapy through a central venous port implanted into his right subclavian area about three months ago. On December 25, 2015, he experienced local pain during fluid injection in the right subclavian area and impossible fluid injection or blood aspiration via venous port. Chest $X$-ray revealed migration of the proximal catheter fragment into the left pulmonary artery (Figure 1). Echocardiography showed preserved left ventricular function with ejection fraction of about $55 \%$ to $60 \%$. No regional wall motion abnormality was observed. Linear shadow in the left pulmonary artery was seen on echocardiography, representing the retained fragment. After the patient was evaluated by a cardiovascular surgeon and interventional cardiologist; an emergency percutaneous removal of the catheter

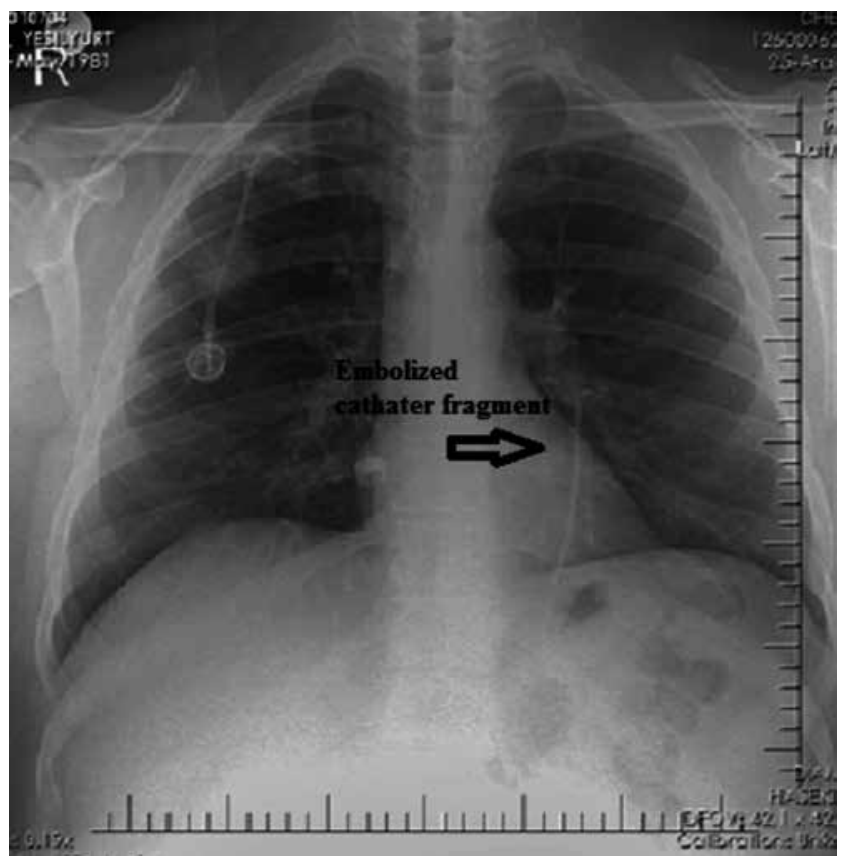

Figure 1. Chest radiograph of a 34 years old man shows cardiac migration of the fragment of a fractured portacath was planned. Thus, he was referred to the interventional cardiology clinic for minimally-invasive percutaneous removal. Therefore, the patient was admitted to our hospital for retrieval of the embolized catheter fragment on the same day. On admission, his vital signs were stable. On the physical examination, there were subcutaneous swelling and erythema in the right subclavian area, and the other physical examination findings were within the normal limits. The patient and his family were informed in detail about the possible consequences of the presence of a foreign material in the left pulmonary artery. After informed consent was obtained, the patient was taken to the cardiac catheterization laboratory. The procedure was performed under local anesthesia and fluoroscopic guidance. A 6-Fr pigtail catheter was advanced to the left pulmonary artery through the right femoral vein using an 8-Fr sheath. Then, the pigtail catheter was exchanged with an 8-Fr guiding catheter. Approximately $10-\mathrm{cm}$ long and 6-Fr diameter fractured catheter segment that was lodged in the left pulmonary artery was successfully grasped by using a $25 \mathrm{~mm}$ snare with triple loops (ev3 ${ }^{\text {TMAmplatz }}$ Goose Neck snare Kit, A111044) and pulled into the right femoral vein along with the sheath and was externalized (Figure 2, 3). We administered intravenous unfractionated heparin at a dose of $70 \mathrm{U} / \mathrm{kg}$ (up to a maximum 5000 $\mathrm{U})$ during the procedure. After the activated partial thromboplastin time was maintained at $<50$ seconds, we
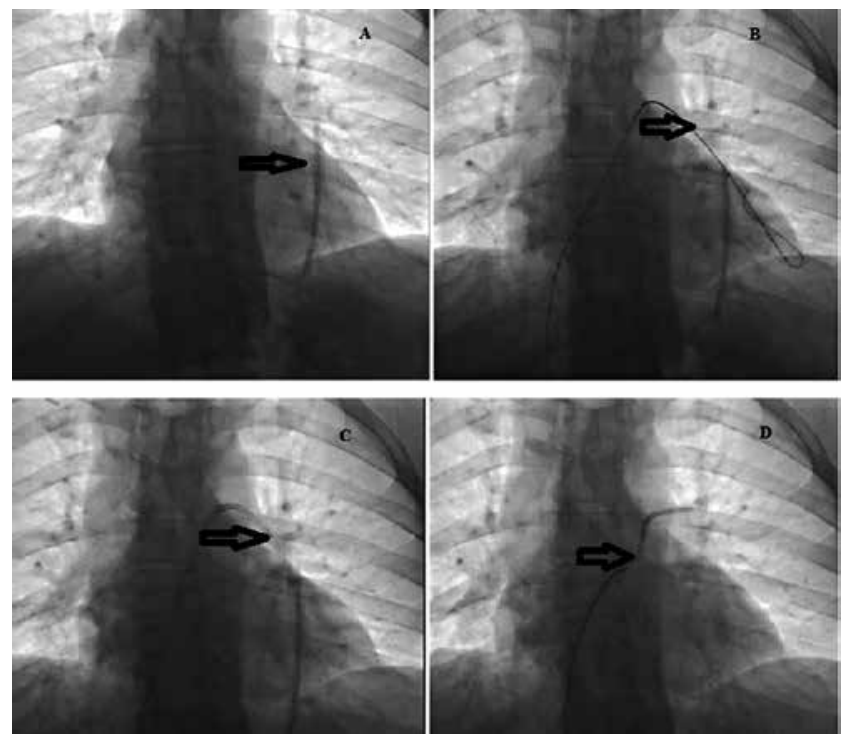

Figure 2. The embolized cathater fragment was seen into the left pulmonary artery (A). The guidewire advanced the left pulmonary arter via 6F pigtail catheter (B). After that, the pigtail catheter was exchanged with 8-Fr guiding catheter (C). Thereafter its distal free end was captured by a snare in SVC and removed successfully. The approximately 10-cm long and 6-Fr diameter fractured catheter segment was successfully grasped by using a 25 $\mathrm{mm}$ snare with triple loops (D) 
removed the femoral vein sheath and hemostasis was achieved through manual pressure. Post-procedure course was uneventful and the nature of vascular access made early ambulation possible.

\section{Discussion}

A broken and migrated peripherally inserted central venous port in the right subclavian vein was successfully retrieved using a snare with triple loops.

Port-a-Cath is a totally implantable venous access device in which a conventional central venous catheter is attached to a subcutaneous injection port usually on the chest wall. It has been reported that application of port catheters is safe. Complications after catheter insertion include embolization, infection, venous thrombosis, occlusion of the catheters, venous perforation, atrial perforation, arrhythmias, flebitis, leakage, dislodgement, subintimal entrapment, and fracture and/or migration of the catheters (11-15). Port-a-Catheter fracture with or without embolization is a serious and rare complication in adult patients. The estimated incidence is between $0.2 \%$ and $1.1 \%$ of all insertions, and the reported mortality rate is approximately $60 \%(1,5,11,16,17)$. The present case suffered embolization of a broken catheter material into the left pulmonary artery. The intravascular fragment lodges more distally within the pulmonary artery especially in the left pulmonary artery with the risk of causing a pulmonary infarction whereas mostly becomes lodged within the right heart (1). Although the exact mechanism of portacath fructure is unknown, the impingement of the port catheter between the first rib and the clavicle by surrounding musculoskeletal system was thought by many authors as a possible cause, known as "pinch off syndrome" or thoracic inlet syndrome. $(1,16-20)$. It was also supposed that factors such as venous flow, negative

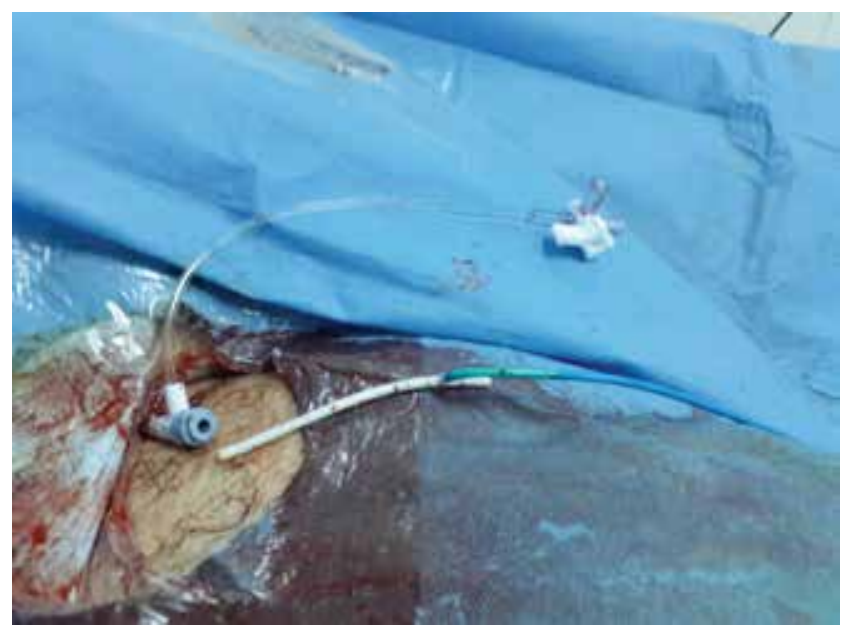

Figure 3. Fractured catheter segment removed by using snare with triple loops inspiratory pressure in the thoracic cavity, changes in thoracic pressure with coughing and vomiting, vigorous movement of the upper arms, neck flexion, were thought to lead to migration of fractured material $(21,22)$. In this case, we could not speculate on the cause of migration in our patient.

The patient in our case report complained of local pain, subcutaneous swelling and erythema in the right subclavian area. Most of the patients with the fractured catheter embolization remain asymptomatic. Besides that, they may complain of palpitation, cough, dyspnea, thoracic pain, or local swelling and erythema due to serious complications such as infection, pulmonary embolism, arrhythmia, cardiac perforation, ventricular tachydysrhythmia, cardiac arrest, and endocarditis. The first sign of catheter embolization mostly is catheter malfunction precluding fluid injection or blood aspiration and or local pain and subcutaneous swelling at the injection site as seen in our case $(2,16,18,22)$. Therefore, prompt removal of the catheter fragments should be done.

While surgery was the only choice in the treatment of broken and migrated catheters in the past, currently, percutaneous transcatheter retrieval of the portacath fractured fragment by interventional endovascular techniques is the most common technique and successfully performed with much lower morbidity and mortality rates when compared with surgery in adult patients even in neonates $(1,5,6,14,23-25)$. The reported success rates of percutaneous retrieval of fractured fragment in the literature are between $71 \%$ and $100 \%(5,17,25)$.

Although, there are several available tools for retrieving intravascular foreign bodies from the vascular system, such as endovascular forceps, pigtail catheter, ablation catheter and retrieval baskets, snare-loop catheter is the most commonly used devise for intravascular catheter fragment retrieval $(1,5,6,23)$. Additionally, the most often preferred access route is the right common femoral vein due to advantages such as convenience in handling material, access to main sites of venous foreign body migration, the possibility of using larger-calibre sheaths, easier puncture procedure, and safety of effective compression after the end of the procedure (17).

In our case, the fragment was successfully removed from the left pulmonary artery using snare with triple loops via the right femoral vein by endovascular technique under local anesthesia.

Catheter fraction and migration into the left pulmonary artery is a rare and potentially severe life-threatening complication with high mortality rate. Therefore, retrieval of embolized fractured catheter material should be considered. Since percutaneous transcatheter retrieval 
using loop-snare is a less invasive, safe, reliable and effective technique, which avoids open surgery and surgeryrelated complications, we suggest that percutaneous transcatheter technique for retrieval of embolized or broken catheter fragments should be considered as the first-choice treatment.

\section{Ethics}

Peer-review: Internally peer-reviewed.

\section{Authorship Contributions}

Surgical and Medical Practices: Mehmet Mustafa Can, Muhsin Kalyoncuoğlu. Concept: Semi Öztürk. Design: Muhsin Kalyoncuoğlu, Gündüz Durmuş. Data Collection or Processing: Gündüz Durmuş. Analysis or Interpretation: Mehmet Mustafa Can, Mustafa Sarı. Literature Search: Semi Öztürk. Writing: Muhsin Kalyoncuoğlu.

Conflict of Interest: No conflict of interest was declared by the authors.

Financial Disclosure: The authors declared that this study received no financial support.

\section{References}

1. Bouzelmat H, Kheyi J, Raissuni Z, Chaib A, Moustaghfir A. Percutaneous Extraction of a Catheter Fragment of Totally Implantable Venous Device Migrating into the Left Pulmonary Artery. J Clin Exp Cardiolog 2014;5:324.

2. Wassef A. WA, Kass M, Parmar G, Ravandi A. An unusual cause of ventricular tachycardia: Port-A-Cath fracture and embolization into the pulmonary artery. Heart Int 2014;9:30-2.

3. Teragawa H, Sueda T, Fujii $Y$, et al. Endovascular technique using a snare and suture for retrieving a migrated peripherally inserted central catheter in the left pulmonary artery. World J Cardiol 2013;5:369-72.

4. Ananthakrishnan G, McDonald R, Moss J, Kasthuri R. Central venous access port devices-a pictorial review of common complications from the interventional radiology perspective. J Vasc Access 2012;13:9-15.

5. Şenocak F, Örün UA, Ceylan Ö, Doğan V, Keskin M, Karademir S. Percutaneous Transvenous Removal of an Entire Detached Port Catheter by Using a Snare-Loop Catheter in a 13-MonthOld Child. J Turgut Ozal Med Cent 2011;18:263-5.

6. Ghaderian M, Sabri MR, Ahmadi AR. Percutaneous retrieval of an intracardiac central venous port fragment using snare with triple loops. J Res Med Sci 2015;20:97-9.

7. Motta Leal Filho JM, Carnevale FC, Nasser F, et al. Endovascular techniques and procedures, methods for removal of intravascular foreign bodies. Rev Bras Cir Cardiovasc 2010;25:202-8.

8. Kawata M, Ozawa K, Matsuura T, et al. Percutaneous interventional techniques to remove embolized silicone port catheters from heart and great vessels. Cardiovasc Interv Ther 2012;27:196-200.

9. Liem TK, Yanit KE, Moseley SE, et al. Peripherally inserted central catheter usage patterns and associated symptomatic upper extremity venous thrombosis. J Vasc Surg 2012;55:761-7.

10. Teragawa $H$, Sueda T, Fujii $Y$, et al. Endovascular technique using a snare and suture for retrieving a migrated peripherally inserted central catheter in the left pulmonary artery. World J Cardiol 2013;5:369-72.

11. Choksy P, Zaidi SS, Kapoor D. Removal of intracardiac fractured port-A catheter utilizing an existing forearm peripheral intravenous access site in the cath lab. J Invasive Cardiol 2014;26:75-6.

12. Amerasekera SS, Jones CM, Patel R, Cleasby MJ. Imaging of the complications of peripherally inserted central venous catheters. Clin Radiol 2009;64:832-40.

13. Kock HJ, Pietsch M, Krause U, Wilke H, Eigler FW. Implantable vascular access systems: Experience in 1500 patients with totally implanted central venous port systems. World J Surg 1998;22:12-6.

14. Cakır F, Geze S, Ozturk MH, Dınc H. Percutaneous endovascular removal of intracardiac migrated port: $A$ catheter in a child with acute lymphoblastic leukemia. Braz J Anesthesiol 2014;64:275-7.

15. Polderman $\mathrm{KH}$, Girbes AJ. Central venous catheter use. Part 1: mechanical complications. Intensive Care Med 2002;28:1-17.

16. Samad AMA, Ibrahim YA. Complications of Port A Cath implantation: A single institution experience. The Egyptian Journal of Radiology and Nuclear Medicine 2015;46:907-11.

17. de Castro Bienerti IR, Chiozzi RLLAF, Mota Carlos EC, Braga JS, Bombanato R, Kajita LJ. Percutaneous Removal of Intravascular Catheter Fragment-an Adaptation of the Toolbox. Rev Bras Cardiol Invasiva 2013;21:291-4.

18. Çilingiroğlu M, Akkuş NI. Embolization of a PORT-A-CATH device in the main pulmonary artery and its percutaneous extraction in a patient with pinch-off syndrome. Türk Kardiyol Dern Ars 2012;40:162-4.

19. Cil BE, Canyiğit M, Peynircioğlu B, et al. Subcutaneous venous port implantation in adult patients: a single center experience. Diagn Interv Radiol 2006;12:93-8.

20. Cho JB, Sung IY, Baek JM, Lee JH, Lee DS. Pinch-off syndrome. J Korean Surg Soc 2013;85:139-44.

21. Dagdelen S, Yuce M, Caglar N. Percutaneous removal of two intracardiac and pulmonary truncal catheter fragment by using a snare-loop catheter. Int J Cardiol 2007;116:413-5.

22. Doley RP, Brar P, Chaudhary S, Bedi R, Swami AC, Wig JD. Port catheter fracture and migration in Internal Jugular Vein. Am J Case Rep 2012;13:14-6.

23. Önal B, Coşkun B, Karabulut R, Ilgıt ET, Türkyilmaz Z, Sönmez $K$. Interventional radiological retrieval of embolized vascular access device fragments. Diag Interv Radiol 2012;18:87-91.

24. Motta Leal Filho JM, Carnevale FC, Nasser F, et al. Endovascular techniques and procedures, methods for removal of intravascular foreign bodies. Rev Bras Cir Cardiovasc 2010;25:202-8.

25. Santos MA, Silva AG, Pivatelli FC, Godoy MF. Retirada de corpo estranho na artéria pulmonar de neonato por técnica intravascular. Rev Bras Cardiol Invas 2008;16:362-4. 